\title{
Peranan Penyuluh Pertanian Lapangan (PPL) sebagai Fasilitator dalam Penggunaan Metode Belajar Pendidikan Orang Dewasa (Andragogi) (Kasus di Gapoktan Madani, Desa Sampalan Klod, Kecamatan Dawan, Kabupaten Klungkung, Provinsi Bali)
}

\author{
HADI SURYO WIBOWO, NYOMAN SUTJIPTA, \\ I WAYAN WINDIA
}

\author{
Program Studi Agribisnis, Fakultas Pertanian, Universitas Udayana \\ J1. PB. Sudirman Denpasar 80323, Bali \\ Email: hadysurya.wibawa11@gmail.com \\ nsutjipta@yahoo.com
}

\begin{abstract}
The Role of Agricultural Field Extensionist (PPL) as a Facilitator in Using Adult Learning Method (Andragogy), (Case in Gapoktan Madani, Sampalan Klod Village, Dawan Sub-district, Klungkung Regency, Bali Province)
\end{abstract}

Agricultural extension acts as an agent for the change of farmers, which is by encouraging farmers to change their perceptions and behaviors to become farmers with better ability and able to make their own decisions, which in turn will gain a better life.The importance of the extensionist role and the importance of an innovation conveyed by him, the extension agent should be able to become a facilitator who can foster and improve the ability of farmers in an effort to change lives for the better. This study aims to identify the role of the extension facilitators in using adult education methods (andragogy). This research was conducted in a combination of farmer group (Gapoktan) Madani, Sampalan Klod Village, Dawan Sub-district, Klungkung Regency, Bali Province. The location of this study was chosen purposively or deliberately based on several considerations. The respondent collected using census method in accordance with the number of active members of the farmer group as many as 60 people. This research uses the descriptive qualitative analysis method, which aims to give description and explanation about variables studied. Based on the results of the research, it is known that the role of agricultural field extension as a facilitator in the use of adult education learning method (andragogy) is included in the good category with the achievement score of 4.11. This means that the extension officer in Gapoktan Madani has been able to perform his role well as a facilitator in the use of adult education learning method (andragogy).

Keywords: role, extension, facilitator, adult education (andragogy), group of farmer (gapoktan) 


\section{Pendahuluan}

\subsection{Latar Belakang}

Kegiatan penyuluhan dalam pembangunan pertanian berperan sebagai jembatan yang menghubungkan antara praktek yang dijalankan oleh petani dengan pengetahuan dan teknologi petani yang selalu berkembang menjadi kebutuhan para petani tersebut (Kartasapoetra,1994) Penyuluh pertanian merupakan orang yang bekerja dalam kegiatan penyuluhan yang melakukan komunikasi pada sasaran penyuluhan, sehingga sasarannya itu mampu melakukan proses pengambilan keputusan dengan benar. Tugas pokok penyuluh pertanian adalah menyuluh, selanjutnya dalam menyuluh dapat dibagi menjadi menyiapkan, melaksanakan, mengembangkan, mengevaluasi, dan melaporkan kegiatan penyuluhan (Badan Pengembangan SDM Pertanian, 2010).

Peran penyuluh pertanian sebagai petugas yang mempersiapkan para petani dan pelaku usaha pertanian lain sudah mulai tumbuh yang antara lain dicirikan dari kemampuannya dalam mencari, memperoleh dan memanfaatkan informasi, serta tumbuh dan berkembangnya lembaga-lembaga pendidikan keterampilan yang dikelola oleh petani sendiri. Sejalan dengan berubahnya paradigma pembangunan pertanian, maka penyelenggaraan penyuluh pertanian dilakukan melalui pendekatan partisipatif untuk lebih meningkatkan peran serta aktif petani dan pelaku usaha pertanian lainnya (Deptan, 2008). Menyadari betapa pentingnya peranan penyuluh pertanian, maka penyuluh pertanian sudah seharusnya mampu menjadi fasilitator yang berperan dalam proses pendampingan alih teknologi suatu inovasi terhadap suatu kelompok tani. Seorang fasilitator diharapkan dapat memfasilitasi apa yang dibutuhkan oleh petani serta membantu mengatasi permasalahan yang timbul dan membutuhkan solusi yang tepat dalam penangananya di lapangan.

Penyuluh pertanian lapangan berkewajiban memiliki konsep-konsep pembelajaran untuk menunjang peranya sebagai fasilitator yang akan menjadi jembatan dalam proses difusi inovasi serta pemecahan masalah dalam suatu organisani. Salah satu konsep yang harus dikuasai yakni konsep pendidikan orang dewasa atau yang biasa disebut dengan andragogi. Andragogi merupakan salah satu alternatif konsep pengembangan pendidikan luar sekolah. Konsep pendidikan yang menekankan pada proses pendewasaan masyarakat dalam konteks luas. Pendidikan orang dewasa (andragogi) berbeda dengan pendidikan anak-anak (pedagogi). Pendidikan orang dewasa berlangsung dalam bentuk pengarahan diri sendiri untuk memecahkan masalah (Suprijanto, 2007).

\subsection{Rumusan Masalah}

Berdasarkan latar belakang, maka permasalahan yang akan dikaji dalam penelitian ini yakni bagaimana peranan penyuluh Pertanian Lapangan sebagai Fasilitator dalam penggunaan metode belajar pendidikan orang dewasa (andragogi) di Gabungan Kelompok Tani Madani, Desa Sampalan, Kecamatan Dawan, Kabupaten Klungkung, Provinsi Bali. 


\subsection{Tujuan Penelitian}

Tujuan penelitian ini untuk mengetahui bagaimana peranan penyuluh pertanian lapangan dalam menjalankan perannya sebagai fasilitator dalam menggunakan metode belajar pendidikan orang dewasa (andragogi) di Gabungan Kelompok Tani Madani, Desa Sampalan, Kecamatan Dawan, Kabupaten Klungkung, Provinsi Bali.

\section{Metode Penelitian}

\subsection{Lokasi dan Waktu Penelitian}

Penelitian ini dilakukan di Gapoktan Madani, Desa Sampalan Kelod, Kecamatan Dawan, Kabupaten Klungkung, Provinsi Bali. Penelitian ini juga akan dilakukan selama tiga bulan yaitu bulan Desember 2016 hingga Maret 2017, mulai dari persiapan hingga penyusunan hasil. Pemilihan lokasi ini dilakukan dengan metode purposive yaitu suatu metode penentuan lokasi penelitian secara sengaja dengan didasari oleh berbagai pertimbangan.

\subsection{Data Penelitian}

Jenis data yang digunakan dalam penelitian ini yakni data kuantitatif dan data kualitatif. Data kuantitatif merupakan data yang dapat dihitung dan dalam bentuk angka dengan satuan tertentu (Antara, 2014). Data kuantitatif meliputi karakterisitik responden, kemudian data kualitatif meliputi penjelasan serta uraian-uraian yang diberikan oleh responden.

Sumber data dalam penelitian ini meliputi data primer dan data sekunder. Data Primer merupakan data berupa hasil wawancara secara langsung kepada narasumber (Antara, 2014). Data primer diperoleh melalui survei yaitu dengan cara mendatangi dan mewawancarai responden maupun informan kunci dengan menggunakan kuisioner. Data sekunder dalam penelitian ini digunakan untuk mengetahui keadaan umum lokasi peelitian meliputi dokumen-dokumen desa, sarana yang dimiliki dan kelembagaan Gapoktan, literatur, artikel.

\subsection{Metode Pengumpulan Data}

Pengumpulan data dalam penelitian ini meliputi wawancara, wawacara mendalam, focus group discussion (FGD) dan dokumentasi. Adapun instrumen yang digunakan yakni kuisioner/angket.

\subsection{Populasi, Responden (Sampel) dan Informan Kunci}

Populasi dalam penelitian ini sebanyak 60 orang. Responden adalah bagian dari jumlah dan karakteristik yang diwakili oleh populasi tersebut (Sugiyono, 2010). Responden/sampel penelitian ini meliputi seluruh anggota aktif gapoktan yang berjumlah 60 orang. Penentuan responden (sampel) dalam penelitian ini menggunakan metode sensus (sampling jenuh) atau teknik penentuan responden bila semua anggota populasi digunakan sebagai responden (Sugiyono, 2012), kemudian 
informan kunci yang dipilih berjumlah lima orang yakni terdiri dari satu orang ketua gapoktan beserta empat orang ketua dari masing-masing poktan.

\subsection{Variabel dan Pengukuran}

Variabel digunakan untuk mengetahui peranan penyuluh pertanian lapangan sebagai fasilitator dalam penggunaan metode belajar pendidikan orang dewasa (andragogi) yaitu penyediaan infrastruktur penunjang kegatan belajar, penyediaan sumber dan media belajar, penggunaan metode belajar, memotivasi peserta belajar dan keahlian PPL. Semua indikator diukur dengan pemberian skor. Skor 1 merupakan skor minimum dan skor 5 merupakan skor maksimum. Skor yang telah diperoleh selanjutnya akan didistribusikan dalam kategori atau kelas dengan menggunakan rumus interval kelas. Interval yang diperoleh sebesar 0,8 .

\subsection{Analisis data}

Analisis data merupakan proses mencari dan menyusun secara sistematis data yang diperoleh dari hasil wawancara,catatan lapangan,dan dokumentasi (Sugiyono, 2010). Proses analisis data dalam penelitian ini dilakukan secara deskriptif kualitatif, data rekapitlasi kuisioner dan informasi yang didapatkan di lapangan diseleksi terlebih dahulu, selanjutnya dideskripsikan secara kualitatif, artinya data tersebut diinterpretasikan dengan kata-kata dan kalimat yang berkaitan dengan penelitian.

\section{Hasil dan Pembahasan}

\subsection{Peranan Penyuluh Pertanian Lapangan sebagai Fasilitator dalam Penggunaan Metode Belajar Pendidiakan Orang Dewasa.}

Peranan juga merupakan penilaian sejauh mana fungsi seseorang atau bagian dalam menunjang usaha pencapaian tujuan yang ditetapkan atau ukuran mengenai hubungan dua variabel yang mempunyai sebab akibat (Soekanto, 2002). Hasil penelitian menunjukkan bahwa peranan PPL sebagai fasilitator dalam penggunaan metode belajar pendidikan orang dewasa di Gapoktan Madani tergolong dalam kategori baik dengan pencapaian skor 4,11. Variabel yang akan diukur yaitu, penyediaan fasilitas infrastruktur penunjang kegiatan, penyediaan fasilitas sumber dan media belajar, penggunaan metode belajar, cara memotivasi peserta ajar dan akan diukur juga keahlian PPL dalam menjalankan peranya. Berikut disajikan hasil penelitian peranan PPL dalam penggunaan metode belajar pendidikan orang dewasa pada Tabel 1. 


\section{Tabel 1.}

Peranan PPL sebagai Fasilitator dalam Penggunaan Metode Belajar Pendidikan Orang Dewasa di Gapoktan Madani, Tahun 2017 Dilihat dari rata-rata Pencapaian Skor untuk Masing-masing Variabel

\begin{tabular}{clcc}
\hline No & \multicolumn{1}{c}{ Variabel } & Pencapaian Skor & Kategori \\
\hline 1 & Penyediaan Infrastruktur Penunjang Kegiatan & 4,20 & Baik \\
2 & Penyediaan Sumber Dan Media Belajar & 3,95 & Baik \\
3 & Penggunaan Metode Belajar & 4,13 & Baik \\
4 & Memotivasi Peserta Didik & 3,98 & Baik \\
5 & Kahlian PPL & 4,30 & Sangat Baik \\
\hline Peranan PPL sebagai fasilitator & 4,11 & Baik \\
\hline
\end{tabular}

Hal ini menunjukan bahwa penyuluh yang bertugas di Gapoktan Madani, Kecamatan Dawan, Kabupaten Klungkung sudah mampu berperan dengan baik meskipun dalam kegiatannya mengalami hambatan-hambatan, namun penyuluh masih mampu mengatasi hambatan tersebut. Penyuluh Pertanian Lapang dapat menjalankan perannya sebagai fasilitator dalam menggunakan metode belajar pendidikan orang dewasa (andragogi) dengan baik pada Gabungan Kelompok Tani Madani, Desa Sampalan Klod, Kecamatan Dawan, Kabupaten Klungkung.

\subsubsection{Peranan PPL dalam penyediaan fasilitas/ infrastruktur penunjang proses belajar}

Hasil penelitian peranan PPL dalam hal penyediaan fasilitas / inrastruktur penunjang proses belajar dengan metode belajar andragogi memperoleh kategori baik dengan pencapaian skor komulatif sebesar 4,20. Berikut dapat disajikan hasil penelitian peranan PPL dalam memfasilitasi penyediaan fasilitas infrastruktur penunjang proses belajar padaTabel 2 .

Tabel 2.

Peranan PPL dalam Memfasilitasi Penyediaan Fasilitas Infrastruktur Penunjang Proses Belajar di Gapoktan Madani

\begin{tabular}{llcc}
\hline No & \multicolumn{1}{c}{ Indikator } & Pencapaian Skor & Kategori \\
\hline 1 & $\begin{array}{l}\text { Penyediaan alat bantu visual (proyektor/papan } \\
\text { tulis) }\end{array}$ & 4,08 & Baik \\
2 & $\begin{array}{l}\text { Penyediaan alat bantu pendengaran (pengeras } \\
\text { suara) }\end{array}$ & 4,43 & Sangat Baik \\
3 & Penyediaan tempat belajar yang lapang & 3,93 & Baik \\
4 & Penyediaan tempat belajar yang bersih & 4,15 & Baik \\
5 & $\begin{array}{l}\text { Penyediaan lahan praktik lapangan/demplot mudah } \\
\text { di akses }\end{array}$ & 4,22 & Sangat Baik \\
6 & $\begin{array}{l}\text { Penyediaan snack/kudapan/jajan } \\
7\end{array}$ & 4,15 & Baik \\
\hline Penyediaan air mineral & 4,40 & Sangat Baik \\
penunjang proses belajar & PPL dalam penyediaan fasilitas infrastruktur & 4,20 & Baik \\
\hline
\end{tabular}


Pencapaian skor tertinggi adalah penyediaan alat bantu pendengaran/pengeras suara saat kegiatan penyuluhan dilakukan dengan kategori sangat baik dengan pencapain skor 4,43 . Hasil wawancara yang sudah dilaksanakan, pencapaian skor yang diperoleh, PPL selalu menggunakan alat bantu paling tidak speaker/microphone sehingga informasi yang disampaikan dapat dengan mudah didengarkan dan dimengerti oleh peserta belajar.

\subsubsection{Peranan PPL dalam penyediaan fasilitas sumber dan media belajar}

Media penyuluhan dapat digunakan untuk mengemas informasi dan teknologi yang akan disampaikan kepada sasaran sebagai pengguna informasi ataupun teknologi, seperti media cetak (buku edukasi, pamflet, brosur, tutorial), media audio visual (film, ilustrasi, gambar), media berupa obyek fisik atau benda nyata yang berkaitan dengan materi belajar dalam menunjang proses pembelajaran.

Hasil penelitian dari variabel penyediaan fasilitas sumber belajar dan media belajar mendapatkan skor komulatif sebesar 3,95 dengan kategori baik. Berikut dapat disajikan hasil penelitian peranan PPL dalam penyediaan fasilitas sumber dan media belajar pada Tabel 3 .

Tabel 3.

Peranan PPL dalam Memfasilitasi Penyediaan Sumber dan Media Belajar Penunjang Proses Pembelajaran di Gapoktan Madani

\begin{tabular}{clcc}
\hline No & \multicolumn{1}{c}{ Indikator } & Pencapaian Skor & Kategori \\
\hline 1 & Penyediaan pamflet / brosur & 3,93 & Baik \\
2 & Penyediaan buku edukasi & 3,75 & Baik \\
3 & $\begin{array}{l}\text { Penyediaan foto, film dan ilustrasi penunjang } \\
\text { proses belajar }\end{array}$ & 4,25 & Sangat baik \\
4 & $\begin{array}{l}\text { Penyediaan bahan ajar demplot lapangan } \\
\text { (tutorial/langkah-langkah) }\end{array}$ & 3,78 & Baik \\
5 & $\begin{array}{l}\text { Penyediaan bahan / alat peraga yang berkaitan } \\
\text { dengan materi demplot }\end{array}$ & 4,05 & Baik \\
\hline Peranan PPL dalam penyediaan sumber dan media belajar & 3,95 & Baik \\
\hline
\end{tabular}

Penyediaan sumber-sumber pembelajaran serta media belajar sangatlah dibutuhkan dalam suatu proses belajar yang mana hal ini bertujuan untuk menunjang dari proses pembelajaran itu sendiri. Penyediaan foto, film dan ilustrasi dalam proses belajar memperoleh skor kategori sangat baik dengan pencapaian skor 4,25, sejalan dengan hasil wawancara yang menyatakan dalam menunjang proses belajar PPL selalu menyempatkan untuk menampilkan foto, film maupun ilustrasi dalam setiap kesempatan, dimana hal ini dikatakan sangat membantu mempercepat peserta belajar untuk dapat mengerti materi yang diberikan dalam kegiatan belajar.

\subsubsection{Peranan PPL dalam Penggunaan Metode Belajar}

Peranan PPL sebagai fasilitator dalam metode belajar pendidikan orang dewasa tidak terlepas dari pemilihan dan penggunaan metode serta teknik pembelajaran. 
Maka, dalam praktek pelatihan selain pengenalan informasi melalui ceramah diharapkan pula lebih banyak penggunaan diskusi kelompok, curah pendapat, sekolah lapangan, melakukan praktek dan lain sebagainya, yang pada dasarnya berupaya untuk melibatkan peranserta atau partisipasi peserta pelatihan.

Hasil dari penelitian peranan PPL sebagai fasilitator pendidikan orang dewasa pada variabel penggunaan metode belajar diperoleh kategori baik dengan pencapaian skor komulatif sebesar 4,13. Berikut dapat disajikan hasil penelitian peranan PPL dalam penggunaan metode belajar pada Tabel 4.

\section{Tabel 4.}

Peranan PPL dalam Penggunaan Metode Belajar Berasaskan Metode Belajar Orang Dewasa di Gapoktan Madani

\begin{tabular}{clcc}
\hline No & \multicolumn{1}{c}{ Indikator } & Pencapaian Skors & Kategori \\
\hline 1 & $\begin{array}{l}\text { Pelibatkan anggota kelompok dalam penyusunan } \\
\text { program balajar }\end{array}$ & 4,38 & Sangat Baik \\
2 & $\begin{array}{l}\text { Pelibatan anggota kelompok dalam penyelesaian } \\
\text { masalah bersama }\end{array}$ & 4,13 & Baik \\
3 & $\begin{array}{l}\text { Pelibatkan anggota kelompok dalam melakukan } \\
\text { evaluasi belajar }\end{array}$ & 4,32 & Sangat Baik \\
4 & Penggunaan metode ceramah & 3,98 & Baik \\
5 & Penggunaan metode kursus/demonstrasi & 3,82 & Baik \\
6 & Penggunaan metode aplikasi/plot di lapangan & 4,28 & Sangat Baik \\
7 & Penggunakan metode curah pendapat. & 3,90 & Baik \\
8 & Penggunakan metode tanya jawab. & 4,22 & Sangat Baik \\
\hline \multicolumn{2}{l}{ Peranan PPL dalam penggunaan metode belajar } & 4,13 & Baik \\
\hline
\end{tabular}

Metode pembelajaran merupakan sebuah strategi dalam proses belajar mengajar dengan tujuan untuk keberhasilan pengajar dalam menyampaikan materi pelajaran. Pencapaian skor tertinggi terdapat pada pelibatan anggota kelompok dalam penyusunan program belajar dengan pencapaian skor 4,38, dari hasil wawancara dinyatakan bahwa PPL selalu melibatkan anggota kelompok untuk turut berperan aktif dalam penyusunan program belajar. Hal ini sejalan dengan yang disampaikan oleh Sudjana, 1989 dan Knowles, 1975, (dalam Jarvis 1992) bahwa peserta didik menyusun program atas dasar aktivitas dan kemampuan mereka sendiri dengan modal pengetahuan, keterampilan, serta sumber yang ada dan dapat mereka gunakan.

\subsubsection{Peranan PPL dalam memotivasi peserta didik}

Penyuluh sebagai fasilitator dalam menjalankan peranya memfasilitasi segala kebutuhan peserta ajar dalam proses belajar PPL juga diharuskan memiliki kemampuan untuk memberikan dorongan ataupun motivasi dalam upaya peningkatan partisipasi dari peserta didik baik dalam kegiatan belajar maupun dalam kegiatan pelaksanaanya. Hasil penelitian peranan PPL sebagai fasilitator pendidikan orang dewasa dalam variabel memotivasi peserta didik didapatkan pencpaian skor komulatif sebesar 3,98 dengan kategori baik. 
Hasil baik ini sejalan dengan yang di ungkapkan oleh Nasution (1990) yang menyatakan bahwa PPL seharusnya berfungsi sebagai motivator yang tangguh atau orang yang membangkitkan motivasi kelompok yang dibinanya dalam tugas sebagai penyuluh pertanian. Berikut dapat disajikan hasil penelitian peranan PPL dalam memotivasi peserta didik pada Tabel 5.

Tabel 5.

Peranan PPL dalam Memotivasi Peserta Belajar di Gapoktan Madani

\begin{tabular}{clcc}
\hline No & \multicolumn{1}{c}{ Indikator } & Pencapaian Skor & Kategori \\
\hline 1 & Meningkatkan kehadiran anggota kelompok & 4,58 & Sangat Baik \\
2 & Meningkatkan kemauan untuk mengikuti & 4,12 & Baik \\
& kegiatan penyuluhan & 3,53 & Baik \\
3 & Meningkatkan kemauan mencoba hal baru & 3,70 & Baik \\
4 & Meningkatkan keberanian dan kemauan untuk & & Baik \\
\hline
\end{tabular}

Berdasarkan Tabel 5, pencapaian skor tertinggi terdapat pada indikator memotivasi untuk dapat meningkatkan tingkat kehadiran dalam kegiatan belajar. Hal ini didukung hasil wawancara bahwa PPL dalam setiap kesempatan selalu mengajak serta menjelaskan kapada seluruh anggota untuk ikut serta dalam proses belajar baik itu mulai dari penyusunan program belajar sampai dengan pelaksanaan penyuluhan.

\subsubsection{Keahlian PPL dalam Melakukan Proses Belajar}

Hasil penelitian peranan PPL sebagai fasilitator pendidikan orang dewasa dalam variabel keahlian PPL dalam melalukan proses belajar memperoleh kategori sangat baik dengan pencapaian skor sebesar 4,30. Variabel keahlian PPL dalam melakukan proses belajar diukur dengan indikator penggunaan bahasa yang mudah dimengerti, cara berkomunikasi yang lugas saat berdiskusi, cara penyampaian informasi/inovasi mudah dipahami, keterampilan menciptakan suasana belajar dan diskusi secara aktif yang, menciptakan suasana belajar yang bersahabat (informal dan santai), kompetensi PPL dalam menyusun program belajar, pemahaman PPL dengan materi yang diberikan, dan kesesuaian materi dengan permasalahan yang ada. Berikut dapat disajikan hasil penelitian keahlian PPL dalam melakukan proses belajar pada Tabel 6. 
Tabel 6.

Keahlian PPL dalam Melakukan Proses Belajar di Gapoktan Madani

\begin{tabular}{clcc}
\hline No & \multicolumn{1}{c}{ Indikator } & Pencapaian Skor & Kategori \\
\hline 1 & Bahasa yang mudah dimengerti & 4,60 & Sangat Baik \\
2 & Cara berkomunikasi yang lugas saat berdiskusi & 4,42 & Sangat Baik \\
3 & $\begin{array}{l}\text { Cara penyampaian informasi/ inovasi yang mudah } \\
\text { di pahami }\end{array}$ & 4,33 & Sangat Baik \\
4 & $\begin{array}{l}\text { Keterampilan menciptakan suasana belajar dan } \\
\text { diskusi yang aktif }\end{array}$ & 4,15 & Baik \\
5 & $\begin{array}{l}\text { Keterampilan menciptakan suasana belajar } \\
\text { bersahabat (informal dan santai) }\end{array}$ & 4,20 & Baik \\
6 & $\begin{array}{l}\text { Keterampilan memimpin diskusi } \\
7\end{array}$ & $\begin{array}{l}\text { Kompetensi ppl dalam menyusun program belajar } \\
8\end{array}$ & $\begin{array}{l}\text { Pemahaman ppl penyuluh terhadap materi yang di } \\
\text { berikan }\end{array}$ \\
9 & $\begin{array}{l}\text { Kesesuaian informasi yang disampaikan dengan } \\
\text { permasalahan yang ada }\end{array}$ & 4,323 & Sangat Baik \\
\hline Keahlian PPL & 4,08 & Sangat Baik \\
\hline
\end{tabular}

Berdasarkan Tabel 6, dapat dilihat pencapaian skor tertinggi berada pada indikator bahasa yang di gunakan oleh PPL dalam proses pembelajaran yang termasuk dalam kategori sangat baik dengan pencapaian skor komulatif sebesar 4,60. Hasil wawancara dengan responden yang telah dilaksanakan sebelumnya, dinyatakan bahwa petugas penyuluh pertanian lapangan (PPL) lebih dominan menggunakan bahasa daerah setempat yakni bahasa Bali sehingga bahasa yang digunakan oleh PPL bisa dengan mudah dimengerti oleh peserta belajar yaitu anggota gapoktan.

\section{Simpulan dan Saran}

Berdasarkan hasil penelitian dapat disimpulkan bahwa, peranan penyuluh pertanian lapangan (PPL) sebagai fasilitator dalam proses belajar berasaskan metode belajar pendidikan orang dewasa (andragogi) di Gabungan Kelompok Tani Madani, Desa Sampalan Klod, Keamatan Dawan, Kabupaten Klungkung termasuk kategori baik dengan pencapaian skor komulatif sebesar 4,11, peran PPL meliputi: (1) Peran PPL dalam penyediaan infrasruktur penunjang kegiatan tergolong kategori baik dengan pencapaian skor sebesar 4,20, (2) Peran PPL dalam peyediaan sumber dan media belajar untuk peserta didik mencapat pencapaian dengan kategori baik dengan skor sebesar 3,95, (3) Pencapaian skor pada peran dalam penggunaan metode belajar memperoleh kategori baik dengan skor sebesar 4,13, (4) Peran dalam upaya meningkatkan motivasi belajar peserta didik mendapatkan kategori baik dengan pencapaian skor sebesar 3,89, dan (5) keahlian petugas penyuluh lapangan (PPL) dalam menjalankan peranya memperoleh kategori sangat baik dan pencapaian skor sebesar 4,30.

Adapun saran yang dapat diberikan terkait penelitian yang telah dilakukan adalah peran PPL dalam memotivasi peserta belajar masih perlu di tingkatkan kembali kembali khususnya dalam peningkatan kemauan mencoba hal baru, tentunya 
dengan pendekatan-pendekatan yang humanis agar tujuan peningkatan kemauan petani dapat berjalan secara maksimal. PPL juga diharapkan kedepanya membuat survei kecil-kecilan mengenai tingkat kepuasan terhadap kinerja PPL. Berdasarkan hasil dari penelitian disaranan pula kepada anggota diharapkan dapat lebih meningkatkan motivasi belajar khususnya dalam mencoba sesuatu inovasi dalam proses belajar.

\section{Ucapan Terima Kasih}

Ucapan terimakasih ini peneliti tujukan kepada ketua Gapoktan Madani, Desa Sampalan Klod, Kecamatan Dawan, Kabupaten Klungkung dan seluruh pihak yang telah membantu dalam pelaksanaan penelitian hingga karya ilmiah ini bisa dipublikasikan dalam bentuk e-jurnal.

\section{Daftar Pustaka}

Antara, M. 2014. Format dan Substansi Proposal Penelitian Sosial Ekonomi. Program Studi Agribisnis Fakultas Pertanian Universitas Udayana. Denpasar

Badan Pengembangan Sumberdaya Manusia Pertanian. 2010. UU No. 16 tahun 2006 Tentang Sistem Penyuluhan Pertanian, Perikanan dan Kehutanan. Departemen Pertanian. Jakarta.

Departemen Pertanian. 2008. Pedoman Umum Pengelolaan Anggaran Pembangunan Pertanian. Jakarta Dinas Pertanian Tanaman Pangan dan Hortikultura. Pemberdayaan Penyuluhan Pertanian.

Kartasapoetra, A. G. 1994. Teknologi Penyuluhan Pertanian. Bumi Aksara. Jakarta. Jarvis, P. 1992. Paradoxes Of Learning. Jassey-Boss Publisher. San Francisco.

Nasution, Z.1990. Prinsip-Prinsip Komunikasi untuk Penyuluhan. Lembaga Penerbit Fakultas Ekonomi Universitas Indonesia, Jakarta

Soekanto, S. 2002. Teori Peranan, Bumi Aksara, Jakarta.

Sugiyono. 2010. Metode Penelitian Bisnis. Penerbit Alfabeta. Bandung. . 2012. Metode Penelitian Kuantitatif, Kualitatif, dan R\&D, Cetakan ke-17. Alfabeta. Bandung.

Suprijanto, H. 2007. Pendidikan Orang Dewasa dari Teori hingga Aplikasi. Bumi Aksara. Jakarta. 